\title{
Rearrangement of $\beta, \gamma$-Unsaturated Esters with Thallium Trinitrate: Synthesis of Indans Bearing a $\beta$-Keto Ester Moiety
}

\author{
Luiz F. Silva Jr., * Eliane C. Pedrozo and Helena M. C. Ferraz, \\ Instituto de Química, Universidade de São Paulo, CP 26077, 05513-970 São Paulo-SP, Brazil
}

\begin{abstract}
$\mathrm{O}$ rearranjo de ésteres $\beta, \gamma$-insaturados, tais como 2-(3,4-di-hidronaftalen-1-il)-propionato de etila, com trinitrato de tálio (TTN) em ácido acético leva a 3-indan-1-il-2-metil-3-oxopropionatos de etila com bom rendimento, através de uma reação de contração de anel. Os novos indanos assim obtidos possuem uma unidade $\beta$-ceto éster, a qual pode ser útil para transformações posteriores.
\end{abstract}

The rearrangement of $\beta, \gamma$-unsaturated esters, such as 2-(3,4-dihydronaphthalen-1-yl)propionic acid ethyl ester, with thallium trinitrate (TTN) in acetic acid leads to 3-indan-1-yl-2methyl-3-oxo-propionic acid ethyl ester in good yield, through a ring contraction reaction. The new indans thus obtained feature a $\beta$-keto ester moiety, which would be useful for further functionalization.

Keywords: indan, ring contraction, thallium trinitrate, $\beta$-keto ester

\section{Introduction}

The indan skeleton is present in a variety of molecules with important biological activity, ${ }^{1}$ including the wellknown Indinavir ${ }^{\circledR}$ and Aricept ${ }^{\circledR} .2,3$ Our research group has investigated approaches to obtain indans from 1,2dihydronaphthalenes, using a thallium(III)-promoted ring contraction reaction..$^{4-9}$ During these studies, we found that a side chain at the double bond has a strong influence in the reaction pathway. ${ }^{5}$ The treatment of 1,2-dihydronaphthalenes bearing a $\beta, \gamma$-unsaturated carboxylic acid unit, such as $\mathbf{1}$, with thallium triacetate (TTA) gave a mixture of the isomeric allylic acetates $\mathbf{2}$ and $\mathbf{3}$, which are produced through an oxidative decarboxylation process (Scheme 1). ${ }^{10}$

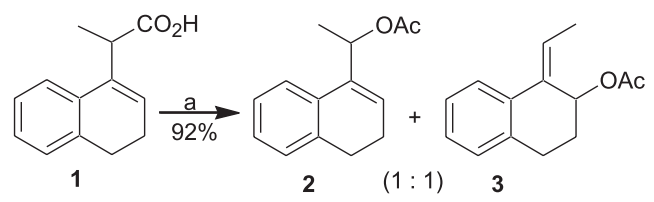

Scheme 1. a) TTA, $\mathrm{CH}_{2} \mathrm{Cl}_{2}, 2$ h, rt.

The reaction of 1,2-dihydronaphthalene with thallium trinitrate (TTN) gave the ring contraction product in very good yield. However, the analogous reaction with 4-alkyl1,2-dihydronaphthalenes afforded mainly products of

*e-mail: luizfsjr@iq.usp.br addition of the solvent, as exemplified for the oxidation of 4 to 5 (Scheme 2). ${ }^{5}$

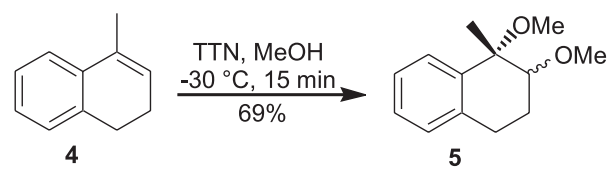

Scheme 2 .

In contrast, the presence of a hydroxyl group at the side chain makes the rearrangement the preferable reaction, as exemplified in the formation of $\mathbf{8}$ from the alkenol 7. ${ }^{4}$ This subtle modification has been attributed to the coordination of the hydroxyl group with the thallium(III), which would help the electrophilic addition step. ${ }^{4,6}$ The homoallylic alcohols 7 were efficiently obtained in three steps from 1-tetralones, through the $\beta, \gamma$ unsaturated esters $\mathbf{6}$. We then realized that these esters would also be interesting substrates for thallium(III)promoted ring contraction reactions, because the indans products of this transformation (9), would bear a $\beta$-keto ester unit, which is a valuable moiety for further functionalization ${ }^{11}$ (Scheme 3).

Herein, a study concerning the synthesis of a series of $\beta$-keto esters 9a-f and $\mathbf{1 1}$ through a TTN-promoted oxidative rearrangement of the readily available $\beta, \gamma$ unsaturated esters 6a-g is described. To the best of our knowledgement, the thallium(III)-mediated rearrangement of $\beta, \gamma$-unsaturated esters has never been reported, although 


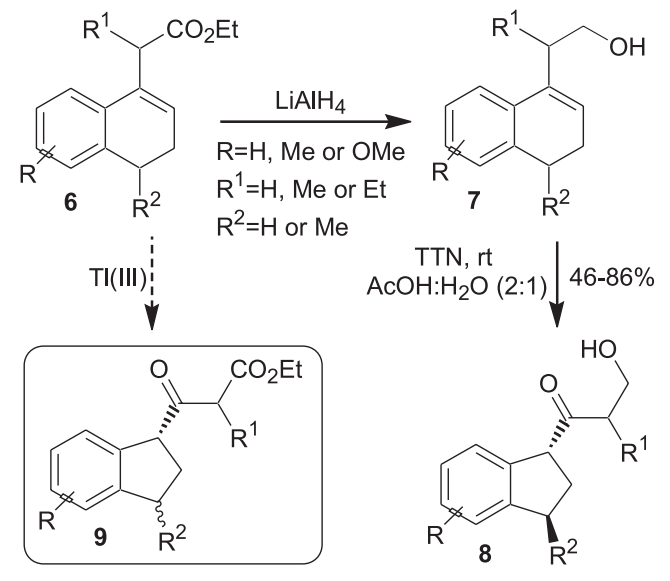

Scheme 3.

the corresponding reaction with $\alpha, \beta$-unsaturated esters has already been described. ${ }^{12}$

\section{Results and Discussion}

The reaction conditions to promote the thallium(III)mediated oxidative rearrangement of $\beta, \gamma$-unsaturated esters were first optimized for the substrate $\mathbf{6 a}$. The first condition tested was that used in the rearrangement of the homoallylic alcohols 7 (see Scheme 3), in other words, TTN in a mixture of acetic acid and water at room temperature. However, under such a condition, the reaction was too slow and even after $21 \mathrm{~h}$ the main component of the reaction mixture was the starting material, as indicated by TLC analysis. Thus, the oxidation of $\mathbf{6 a}$ was performed in glacial $\mathrm{AcOH}$, because in this solvent the solubility of the substrate would increase, which would presumably accelerate the reaction. ${ }^{13}$ Indeed, utilizing two equivalents of TTN in glacial $\mathrm{AcOH}$, the ring contraction product 9a was obtained in good yield (Table 1, entry 1). Using less than two equivalents of TTN, the indan 9a was obtained in lower yield and/or starting material was recovered (1.2 equiv. TTN, $8.5 \mathrm{~h}: 38 \%$ yield and $29 \%$ of starting material recovered; 1.5 equiv. TTN, $28 \mathrm{~h}: 50 \%$ yield). Moreover, the product was also obtained in $\mathrm{ca} .60 \%$ yield, when more than two equivalents of TTN were added (2.5 equiv. TTN, 2 h: $60 \%$; 3.0 equiv. TTN, 2 h: $57 \%$; 3.5 equiv. TTN, 1 h: $63 \%$ ).

With optimized conditions established, we explored the behavior of the substrates $\mathbf{6 b}-\mathbf{g}$. As shown in Table 1, entries $2-7$, in all cases the corresponding indans were obtained from moderate to good yield. When the substrate $\mathbf{6 b}$, which bears the methoxy group in meta to the migrating carbon, reacted with TTN, the ring contraction product was obtained in $49 \%$ yield (entry 2). This lower yield can be explained considering that in the rearrangement of $\mathbf{6 b}$, the negative inductive effect of the methoxy group would predominate, slightly disfavoring the ring contraction. As expected, this inductive effect would be more pronounced in the ester $\mathbf{6 c}$, that bears a bromine atom. Indeed, no reaction was observed when this substrate was treated with TTN under conditions similar to that used with 6a-b (2 equiv. of TTN, AcOH, rt). However, when $\mathbf{6 c}$ was treated with a high excess of TTN, the ring contraction product $9 \mathrm{c}$ was obtained in good yield (entry 3 ).

The oxidative rearrangement of a $\beta, \gamma$-unsaturated ester bearing a methyl group at the cyclohexenyl ring (6f) gave the 1,3-disubstituted indan 9f as a cis/trans mixture, where the trans predominates ${ }^{14}$ (entry 6). We were unable to determine the cis/trans ratio because of the overlap of signals in the NMR spectra of the diastereomers and their corresponding enol forms.

The percentage of enol form of the $\beta$-keto esters 9a-f varies in solution of $\mathrm{CDCl}_{3}$, as indicated in Table 1 . The enol forms 10a-d present a signal at $12.8 \mathrm{ppm}$, corresponding to the $-\mathrm{OH}$ hydrogen, which agrees with the data recently reported by Katritzky and co-workers for analogous enol forms. ${ }^{11}$ The methyl group of the enol forms 10a-c appears as a singlet at $1.9 \mathrm{ppm}$. The hydrogen of the $\mathrm{OH}$ group of the enol forms 10e-f appears at 12.2 ppm and the vinylic hydrogen at ca. $4.9 \mathrm{ppm}$.

The treatment of the ester $\mathbf{6 g}$ with TTN gave the ring contraction product in a yield higher $(72 \%)$ than that obtained for $\mathbf{6 a}$, due to the presence of the methoxy group in para to the migrating carbon, which increases its migratory aptitude, favoring the rearrangement. The isolated ring contraction product is present in solution of $\mathrm{CDCl}_{3}$ exclusively as an enol form, as deduced by ${ }^{1} \mathrm{H}$ and ${ }^{13} \mathrm{C}$ NMR analysis. The ${ }^{13} \mathrm{C}$ NMR spectrum shows 8 signals between 110 and 161 , corresponding to $\mathrm{sp}^{2}$ carbons and a single signal for a carbonyl group, at $172 \mathrm{ppm}$. However, the ${ }^{1} \mathrm{H}$ NMR spectrum shows a dublet at $1.6 \mathrm{ppm}$ and a quartet at $4.1 \mathrm{ppm}$, both having a coupling constant of $7.2 \mathrm{~Hz}$, which indicates the presence of a $\mathrm{CH}_{3}-\mathrm{CH}$ unit. Thus, the expected enol form $\Delta^{2,3}$, analogous to 10a-f, does not fit with these data. However, a nice match between the ${ }^{1} \mathrm{H}$ and ${ }^{13} \mathrm{C}$ NMR signals and the structure 11 was noted (entry 7). ${ }^{15}$ We believe that the enol form 11, on which the double bond is conjugated to the aromatic ring instead to the carbonyl group of the ester, is particularly stable, due to the presence of the methoxy group at the para position.

The ring contraction of $\beta, \gamma$-unsaturated esters mediated by TTN probably occurs by a mechanism similar to that proposed in the rearrangement of the homoallylic alcohols 7., 4 Thus, the first step would be the formation of the oxythallated adduct $\mathbf{1 2}$ that is produced by the electrophilic addition of thallium(III) to the double bond. Such an addition would be assisted by the oxygen of the carbonyl group through coordination with the thallium atom. ${ }^{16}$ Then, the migration of the phenyl group in the adduct $\mathbf{1 2}$ 
Table 1. Reaction of the $\beta, \gamma$-unsaturated esters $\mathbf{6 a - g}$ with $\mathrm{TTN}^{\mathrm{a}}$

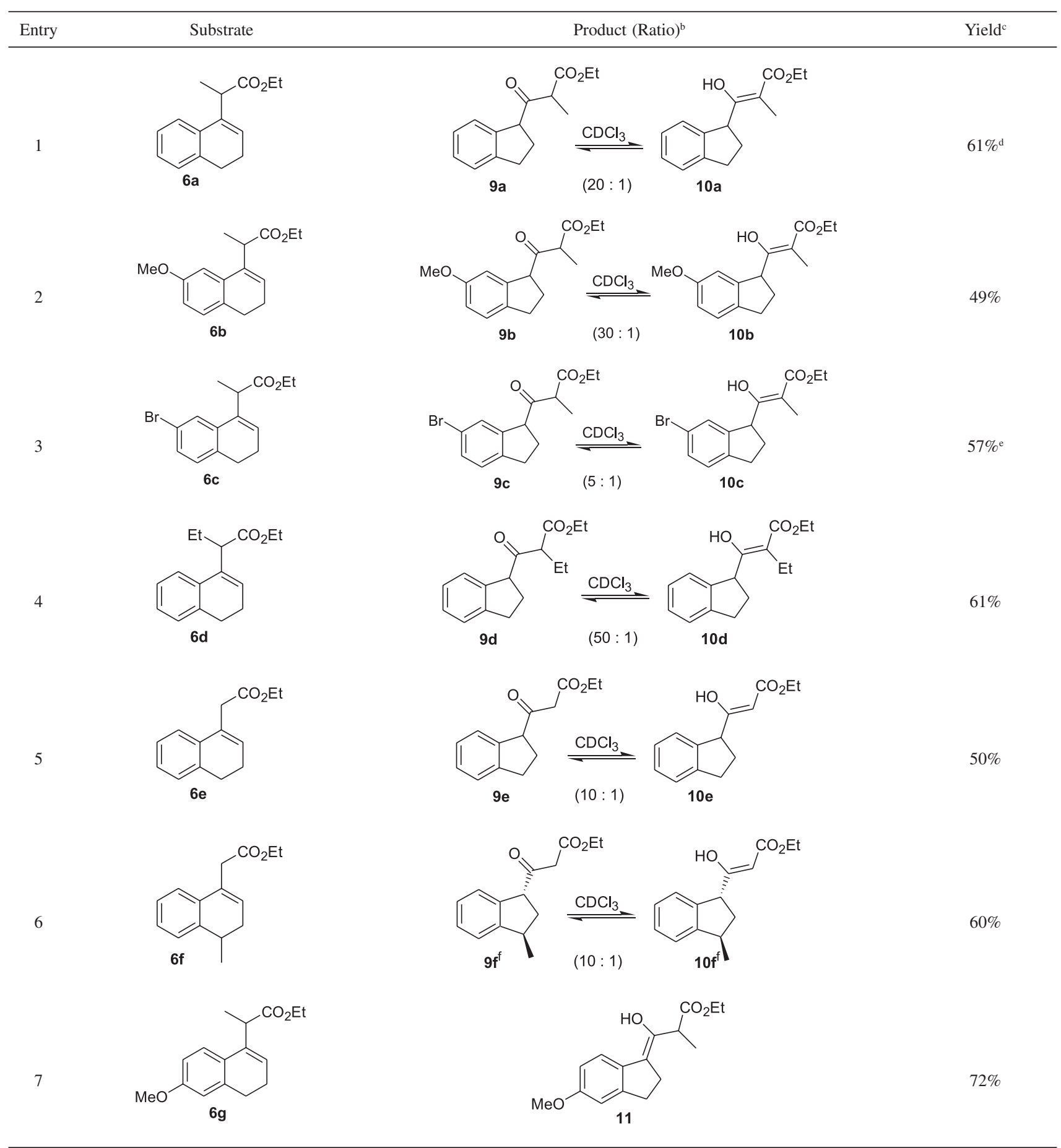

${ }^{a}$ Conditions: 2 equiv. TTN, AcOH, 2 h, rt. ${ }^{b}$ Estimated by ${ }^{1} \mathrm{H}$ NMR. The geometry of the double bond of the enol forms was not established. ${ }^{\mathrm{c}}$ Isolated yield after column chromatography. ${ }^{\mathrm{d}}$ Reaction time: $3 \mathrm{~h} .{ }^{\mathrm{e}}$ Conditions: 8 equiv. TTN, AcOH, 30 min, rt. ${ }^{\mathrm{f}}$ Contaminated with the corresponding cis isomer.

would give the observed product 9a, after losing a proton (Scheme 4). Considering this mechanism, one could expect that the formation of the indans 9 a-d would be diastereoselective, similarly to the observed in the ring contraction of 7.,6 However, the indans 9a-d were obviously isolated as a 1:1 mixture of diastereomers, because the estereocenter flanked by the two carbonyl groups readily epimerizes under the acidic conditions of the reaction medium. Furthermore, the epimerization could also take place by abstraction of the $\alpha$-carbonyl hydrogen of the cyclopentane ring of indans such as $\mathbf{9}$.

In conclusion, a three-step synthesis of indans bearing a $\beta$-keto ester moiety from commercially available ketones was developed. The key transformation in this sequence 


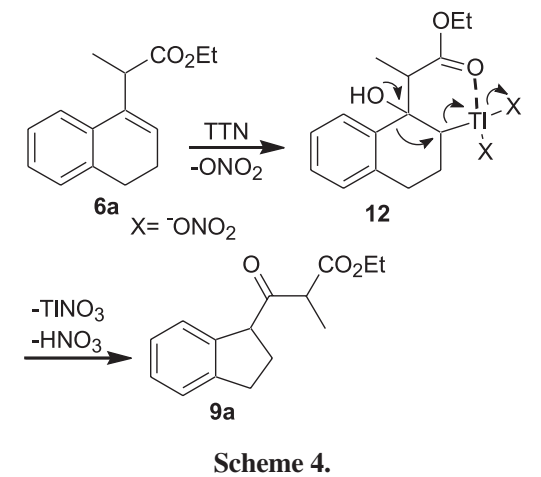

is a thallium(III)-mediated oxidative rearrangement of $\beta, \gamma$-unsaturated esters. The new indans herein described constitute useful building blocks for the synthesis of complex molecules.

\section{Experimental}

\section{General}

The 1-tetralones, ethyl bromoacetate, ethyl 2bromopropionate, and ethyl 2-bromobutyrate were distilled prior to use. Zinc powder was activated by washing several times with $10 \%$ aqueous $\mathrm{HCl}$, water, saturated aqueous $\mathrm{HgCl}_{2}$, water and acetone. The zinc obtained was then dried in an oven ( $\left.c a .120^{\circ} \mathrm{C}\right)$ and storaged in a desiccator. Benzene was distilled from sodium wire and storaged in a bottle also containing sodium wire. THF was used as received for the dehydration reactions. Other reagents were used as received. Column chromatography was performed using silica gel Acros 200-400 Mesh. TLC analyses were performed with silica gel plates Merck, using vanilline or $p$-anisaldehyde solution for visualization. ${ }^{1} \mathrm{H}$ and ${ }^{13} \mathrm{C}$ NMR spectra were recorded on Bruker and/or Varian spectrometers. IR spectra were measured on a Perkin-Elmer 1750FT. Gas chromatography analyses were performed in a HP6890 series II. High resolution mass spectra were acquired on a VG Autospec/Fission Instrument and MicroTOF LC from Bruker Daltonics.

\section{Preparation of the unsaturated esters $\mathbf{6 a}-\mathbf{g}$}

The esters 6a-g were prepared from the corresponding 1-tetralones by Reformatsky followed by acid-catalyzed dehydration, as previously reported. ${ }^{4}$ The analytical data of $\mathbf{6 a}-\mathbf{b}, \mathbf{d}-\mathbf{g}$ were previously reported, whereas the ester $\mathbf{6 c}$ is a new compound.

2-(7-Bromo-3,4-dihydro-naphthalen-1-yl)-propionic acid ethyl ester $(\boldsymbol{6 c})$. Pale yellow oil. IR (film) $v_{\max } / \mathrm{cm}^{-1}: 1735$; ${ }^{1} \mathrm{H}$ NMR (300 MHz, $\left.\mathrm{CDCl}_{3}\right) \delta 1.22(\mathrm{t}, J 7.2 \mathrm{~Hz}, 3 \mathrm{H}), 1.42$ (d, $J 7.2 \mathrm{~Hz}, 3 \mathrm{H}), 2.23-2.30(\mathrm{~m}, 2 \mathrm{H}), 2.63-2.69(\mathrm{~m}, 2 \mathrm{H})$, $3.65(\mathrm{dt}, J 0.9$ and $7.2 \mathrm{~Hz}, 1 \mathrm{H}), 4.06-4.22(\mathrm{~m}, 2 \mathrm{H}), 6.07$ (dt, $J 0.9$ and $4.7 \mathrm{~Hz}, 1 \mathrm{H}), 6.98(\mathrm{~d}, J 7.8 \mathrm{~Hz}, 1 \mathrm{H}), 7.23$ (dd, $J 2.1$ and $7.8 \mathrm{~Hz}, 1 \mathrm{H}), 7.41(\mathrm{~d}, J 1.8 \mathrm{~Hz}, 1 \mathrm{H}) ;{ }^{13} \mathrm{C}$ NMR (75 MHz, $\left.\mathrm{CDCl}_{3}\right) \delta 14.0,16.7,22.7,27.4,41.0$, 60.6, 119.9, 125.3, 127.0, 129.0, 129.3, 135.1, 135.3, 136.1, 174.5; LRMS $\mathrm{m} / z$ (rel. int.) $310\left(\mathrm{M}^{+}, 20 \%\right), 308$ (M+, 13), 295 (3), 293 (3), 235 (16), 209 (9), 207 (9), 156 (53), 141 (51), 128 (68), 102 (100). Anal. Calc. for $\mathrm{C}_{15} \mathrm{H}_{17} \mathrm{O}$ Br: C, 57.91; H, 5.25. Found: C, 58.27; H, 5.54.

3-Indan-1-yl-2-methyl-3-oxo-propionic acid ethyl ester (9a). General procedure for the thallium(III) mediated oxidation of the esters $\mathbf{6} \boldsymbol{a}-\mathbf{g}$

To a stirred solution of $\mathbf{6 a}(0.114 \mathrm{~g}, 0.495 \mathrm{mmol})$ in HOAc $(2.4 \mathrm{~mL})$ was added TTN. $3 \mathrm{H}_{2} \mathrm{O}(0.470 \mathrm{~g}, 1.06$ mmol), which dissolved slowly. The mixture was stirred for $2.5 \mathrm{~h}$ and an abundant precipitation was observed. The resulting suspension was filtered through a silica gel pad (70-230 Mesh, $c a .20 \mathrm{~cm})$, using EtOAc (200 mL), as eluent. The filtrate was washed with a saturated solution of $\mathrm{NaHCO}_{3}$ and the aqueous phase was extracted twice with EtOAc $(50 \mathrm{~mL})$. The organic phase was then dried over anhydrous $\mathrm{MgSO}_{4}$. The residue was purified by flash chromatography (200-400 Mesh, hexanes/EtOAc, 10:1) after concentration of the solvent under reduced pressure, giving a $1: 1$ diastereomeric mixture of the indan 9a $(0.0748 \mathrm{~g}, 0.304$ mmol, 61\%), as a colorless oil. A small amount of the enol form 10a was also detected in the NMR spectra. IR (film) $v_{\text {max }} / \mathrm{cm}^{-1}: 1713,1744 ;{ }^{1} \mathrm{H}$ NMR $\left(300 \mathrm{MHz}, \mathrm{CDCl}_{3}\right) \delta$ keto form: $1.22-1.29(\mathrm{~m}, 3 \mathrm{H}), 1.32-1.36(\mathrm{~m}, 3 \mathrm{H}), 2.22-2.34$ (m, $1 \mathrm{H}), 2.37-2.47(\mathrm{~m}, 1 \mathrm{H}), 2.86-2.99(\mathrm{~m}, 1 \mathrm{H}), 3.03-3.16$ (m, $1 \mathrm{H}), 3.73$ and 3.85 (q, J 7.1 Hz, $1 \mathrm{H}), 4.12-4.23(\mathrm{~m}, 2$ H), 4.28-4.34 (m, 1 H), 7.12-7.31 (m, 4 H). Selected signals for the enol form (other signals overlap with those of the keto form): 1.93 (s, 3H), 12.82 (d, $J 1.5 \mathrm{~Hz}, 1 \mathrm{H}) ;{ }^{13} \mathrm{C} \mathrm{NMR}$ $\left(75 \mathrm{MHz}, \mathrm{CDCl}_{3}\right) \delta$ keto form: 12.93, 13.38, 14.00, 14.01, $29.21,29.50,31.79,31.88,50.92,51.17,56.99,57.22$, $61.28,61.33,124.71,124.93,125.03,126.39,126.44$, $127.56,127.60,140.46,140.49,144.63,144.75,170.36$, 170.43, 205.65, 206.50; LRMS $\mathrm{m} / z$ (rel. int.) $246\left(\mathrm{M}^{+}, 5 \%\right)$, 200 (2), 144 (9), 117 (91); HRMS Calc. for $\mathrm{C}_{15} \mathrm{H}_{18} \mathrm{O}_{3}$ 246.12559; Found 246.12562.

3-(6-Metoxy-indan-1-yl)-2-methyl-3-oxo-propionic acid ethyl ester $(\mathbf{9 b})$

Following the general procedure, a solution of $6 \mathbf{b}(0.159 \mathrm{~g}$, $0.611 \mathrm{mmol})$ in $\mathrm{HOAc}(2.5 \mathrm{~mL})$ was reacted with TTN. $3 \mathrm{H}_{2} \mathrm{O}$ $(0.543 \mathrm{~g}, 1.22 \mathrm{mmol})$ for $2 \mathrm{~h}$. Purification of the crude product by flash chromatography (hexanes/ $\mathrm{Et}_{2} \mathrm{O}, 15: 1$ ) gave a $1: 1$ diastereomeric mixture of the indan $\mathbf{9 b}(0.0819 \mathrm{~g}, 0.296$ 
mmol, 49\%), as a colorless oil. A small amount of the enol form 10b was also detected in the NMR spectra. IR (film) $v_{\text {max }} / \mathrm{cm}^{-1}: 1713,1744 ;{ }^{1} \mathrm{H}$ NMR (300 MHz, $\mathrm{CDCl}_{3}$ ) $\delta$ keto form: 1.25 and 1.27 (t, $J 7.1 \mathrm{~Hz}, 3 \mathrm{H}$ ), 1.33 and 1.34 (d, $J 7.1$ $\mathrm{Hz}, 1 \mathrm{H}), 2.22-2.34(\mathrm{~m}, 1 \mathrm{H}), 2.36-2.45(\mathrm{~m}, 1 \mathrm{H}), 2.81-2.90$ (m, 1H), 2.96-3.05 (m, 1H), 3.72 and $3.83(\mathrm{q}, J 7.1 \mathrm{~Hz}, 1 \mathrm{H})$, 3.77 and 3.78 (s, 3H), 4.17 and $4.18(\mathrm{q}, J 7.1 \mathrm{~Hz}, 1 \mathrm{H}), 4.25$ $4.29(\mathrm{~m}, 1 \mathrm{H}), 6.74-6.85(\mathrm{~m}, 2 \mathrm{H}), 7.13-7.16(\mathrm{~m}, 1 \mathrm{H})$. Selected signals for the enol form (other signals overlap with those of the keto form): 1.92 (s, 3H), $12.82(\mathrm{~d}, J 1.5 \mathrm{~Hz}, 1 \mathrm{H}) ;{ }^{13} \mathrm{C}$ NMR (75 MHz, $\left.\mathrm{CDCl}_{3}\right) \delta$ keto form: 13.00, 13.45, 14.00, 29.80, 29.98, 30.93, 30.99, 50.83, 51.16, 55.41, 55.43, 57.17, $57.51,61.30,61.33,110.35,110.48,113.49,113.88,125.15$, 125.31, 136.55, 136.67, 141.77, 141.83, 158.72, 158.78, 170.36, 170.42, 205.60, 206.42; LRMS $\mathrm{m} / z$ (rel. int.) 276 $\left(\mathrm{M}^{+}, 18 \%\right), 174$ (19), 147 (100). HRMS Calc. for $\mathrm{C}_{16} \mathrm{H}_{20} \mathrm{O}_{4}$ 276.13615; Found 276.13622

3-(6-Bromo-indan-1-yl)-2-methyl-3-oxo-propionic acid ethyl ester $(\mathbf{9 c})$

Following the general procedure, a solution of $\mathbf{6 c}(0.100$ $\mathrm{g}, 0.323 \mathrm{mmol})$ in HOAc $(2.0 \mathrm{~mL})$ was reacted with TTN. $3 \mathrm{H}_{2} \mathrm{O}(1.15 \mathrm{~g}, 2.59 \mathrm{mmol})$ for $40 \mathrm{mim}$. Purification of the crude product by flash chromatography (hexanes/ $\left.\mathrm{Et}_{2} \mathrm{O}, 10: 1\right)$ gave a $1: 1$ diastereomeric mixture of the indan 9c $(0.0600 \mathrm{~g}, 0.185 \mathrm{mmol}, 57 \%)$, as a colorless oil. A small amount of the enol form 10c was also detected in the NMR spectra. IR (film) $v_{\max } / \mathrm{cm}^{-1}: 1714$, 1744; ${ }^{1} \mathrm{H}$ NMR $\left(300 \mathrm{MHz}, \mathrm{CDCl}_{3}\right) \delta$ keto form: 1.25 $1.31(\mathrm{~m}, 3 \mathrm{H}), 1.35-1.39(\mathrm{~m}, 3 \mathrm{H}), 2.18-2.49(\mathrm{~m}, 2 \mathrm{H})$, 2.80-2.92 (m, $1 \mathrm{H}), 2.95-3.10(\mathrm{~m}, 1 \mathrm{H}), 3.71-3.82(\mathrm{~m}, 1$ H), 4.15-2.24 (m, $2 \mathrm{H}), 4.26-4.36(\mathrm{~m}, 1 \mathrm{H}), 7.11(\mathrm{~d}, J$ $8.4 \mathrm{~Hz}, 1 \mathrm{H}), 7.22-7.40(\mathrm{~m}, 2 \mathrm{H})$. Selected signals for the enol form (other signals overlap with those of the keto form): 1.92 (s, 3H), 12.91 (d, J $1.2 \mathrm{~Hz}, 1 \mathrm{H}) ;{ }^{13} \mathrm{C}$ NMR (75 MHz, $\left.\mathrm{CDCl}_{3}\right) \delta$ keto form: 13.02, 13.16, 14.06, $29.72,29.99,31.32,31.47,51.38,56.60,56.71,61.54$, $119.99,120.06,126.09,126.34,127.94,128.26,130.58$, $130.65,142.85,142.90,143.59,143.76,170.25,170.26$ 205.33, 205.81; LRMS $m / z$ (rel. int.) $326\left(\mathrm{M}^{+}, 5 \%\right), 324$ $\left(\mathrm{M}^{+}, 5\right), 224$ (12), 222 (11), 197 (27), 195 (30), 129 (15), 116 (100). Anal. Calc. for $\mathrm{C}_{15} \mathrm{H}_{17} \mathrm{O} 3 \mathrm{Br}$ : C, 55.40; H, 5.27. Found: C, 55.34; H, 5.20.

\section{2-(Indane-1-carbonyl)-butyric acid ethyl ester (9d)}

Following the general procedure, a solution of $\mathbf{6 d}(0.166$ $\mathrm{g}, 0.679 \mathrm{mmol})$ in HOAc $(4.0 \mathrm{~mL})$ was reacted with TTN. $3 \mathrm{H}_{2} \mathrm{O}(0.604 \mathrm{~g}, 1.36 \mathrm{mmol})$ for $2 \mathrm{~h}$. Purification of the crude product by flash chromatography (hexanes/ EtOAc, 10:1) gave a 1:1 diastereomeric mixture of the indan 9d $(0.107 \mathrm{~g}, 0.412 \mathrm{mmol}, 61 \%)$ as a colorless oil. A small amount of the enol form 10d was also detected in the NMR spectra. IR (film) $v_{\max } / \mathrm{cm}^{-1}: 1714,1743 ;{ }^{1} \mathrm{H}$ NMR $\left(300 \mathrm{MHz}, \mathrm{CDCl}_{3}\right) \delta$ keto form: 0.91 and $0.87(\mathrm{t}$, $J 7.5 \mathrm{~Hz}, 3 \mathrm{H}), 1.24$ and $1.26(\mathrm{t}, J 7.2 \mathrm{~Hz}, 3 \mathrm{H}), 1.83-1.96$ (m, 2H), 2.18-2.47 (m, 2H), 2.85-2.98 (m, 1H), 3.02$3.16(\mathrm{~m}, 1 \mathrm{H}), 3.59$ and $3.70(\mathrm{t}, J 7.2 \mathrm{~Hz}, 1 \mathrm{H}), 4.12-4.19$ $(\mathrm{m}, 2 \mathrm{H}), 4.21-4.32(\mathrm{~m}, 1 \mathrm{H}), 7.13-7.30(\mathrm{~m}, 4 \mathrm{H})$. Selected signals for the enol form (other signals overlap with those of the keto form): $12.82(\mathrm{~d}, J 1.5 \mathrm{~Hz}, 1 \mathrm{H}) ;{ }^{13} \mathrm{C} \mathrm{NMR}(75$ $\left.\mathrm{MHz}, \mathrm{CDCl}_{3}\right) \delta$ keto form: $11.83,11.99,14.02,21.57$, $21.85,29.12,29.36,31.68,31.83,57.28,57.37,58.76$, $58.80,61.18,61.21,124.64,124.75,124.89,125.05$, 126.26, 126.34, 127.48, 127.55, 140.26, 144.56, 144.71, 169.51, 169.58, 204.93, 205.54; LRMS m/z (rel. int.) $260\left(\mathrm{M}^{+}, 5 \%\right), 144$ (11), 117 (100.0). HRMS Calc. for $\mathrm{C}_{16} \mathrm{H}_{20} \mathrm{O}_{3}$ 260.1412; Found $261.1488\left(\mathrm{MH}^{+}\right)$.

\section{3-Indan-1-yl-3-oxo-propionic acid ethyl ester (9e)}

Following the general procedure, a solution of $6 \mathbf{e}(0.225$ $\mathrm{g}, 1.04 \mathrm{mmol})$ in HOAc $(4.0 \mathrm{~mL})$ was reacted with TTN. $3 \mathrm{H}_{2} \mathrm{O}(0.926 \mathrm{~g}, 2.09 \mathrm{mmol})$ for $2 \mathrm{~h}$. Purification of the crude product by flash chromatography (hexanes/ $\left.\mathrm{Et}_{2} \mathrm{O}, 10: 1\right)$ gave $9 \mathrm{e}(0.120 \mathrm{~g}, 0.517 \mathrm{mmol}, 50 \%)$ as a colorless oil. A small amount of the enol form 10e was also detected in the NMR spectra. IR (film) $v_{\max } / \mathrm{cm}^{-1}$ : 1713, 1744; ${ }^{1} \mathrm{H}$ NMR $\left(300 \mathrm{MHz}, \mathrm{CDCl}_{3}\right) \delta$ keto form: $1.26(\mathrm{t}, J 7.1 \mathrm{~Hz}, 3 \mathrm{H}), 2.33-2.40(\mathrm{~m}, 2 \mathrm{H}), 2.9-3.1(\mathrm{~m}$, $2 \mathrm{H}), 3.52$ (AB system, $J 15.7 \mathrm{~Hz}, 2 \mathrm{H}), 4.14-4.24(\mathrm{~m}$, $3 \mathrm{H})$, 7.18-7.30 (m, 4H). Selected signals for the enol form (other signals overlap with those of the keto form): 1.27 (t, J 7.1 Hz, 3H), 3.8-3.9 (m, 1H), 4.98 (s, 1H), $12.16(\mathrm{~s}, 1 \mathrm{H}) ;{ }^{13} \mathrm{C}$ NMR $\left(75 \mathrm{MHz}, \mathrm{CDCl}_{3}\right) \delta$ keto form: 14.07, 28.60, 31.76, 47.00, 58.26, 61.34, 124.96, 125.00, 126.64, 127.83, 139.94, 144.65, 167.20, 202.83. LRMS $\mathrm{m} / z$ (rel. int.) $232\left(\mathrm{M}^{+}, 6 \%\right), 144$ (12), 117 (100). HRMS Calc. for $\mathrm{C}_{14} \mathrm{H}_{16} \mathrm{O}_{3}$ 232.1099; Found $233.1184\left(\mathrm{MH}^{+}\right)$.

3-(3-Methyl-indan-1-yl)-3-oxo-propionic acid ethyl ester $(9 f)$

Following the general procedure, a solution of $\mathbf{6} \mathbf{f}(0.158$ $\mathrm{g}, 0.686 \mathrm{mmol})$ in HOAc $(2.5 \mathrm{~mL})$ was reacted with TTN. $3 \mathrm{H}_{2} \mathrm{O}(0.610 \mathrm{~g}, 1.37 \mathrm{mmol})$ for $2 \mathrm{~h}$. Purification of the crude product by flash chromatography (hexanes/ $\left.\mathrm{Et}_{2} \mathrm{O}, 15: 1\right)$ gave $9 \mathrm{f}(0.102 \mathrm{~g}, 0.412 \mathrm{mmol}, 60 \%)$ as a colorless oil. A small amount of the enol form 10f was also detected in the NMR spectra. IR (film) $v_{\max } / \mathrm{cm}^{-1}$ : 1713,$1744 ;{ }^{1} \mathrm{H}$ NMR $\left(300 \mathrm{MHz}, \mathrm{CDCl}_{3}\right) \delta$ keto form: $1.23-1.31(\mathrm{~m}, 6 \mathrm{H}), 1.76-2.02(\mathrm{~m}, 1 \mathrm{H}), 2.60-2.68(\mathrm{~m}, 1 \mathrm{H})$, 3.33-3.45 (m, 1H), 3.5-3.6 (m, 2H), 4.13-4.24 (m, 3H), 
7.17-7.32 (m, 4H). Selected signals for the enol form (other signals overlap with those of the keto form): 4.88 $(\mathrm{m}, 1 \mathrm{H}), 12.15(\mathrm{~m}, 1 \mathrm{H}) ;{ }^{13} \mathrm{C}$ NMR $\left(75 \mathrm{MHz}, \mathrm{CDCl}_{3}\right) \delta$ keto form (trans diastereomer): 14.06, 20.04, 37.60, $38.25,46.95,57.06,61.33,123.95,124.92,126.76$, 128.04, 139.50, 149.31, 167.23, 202.65. LRMS m/z (rel. int.) $246\left(\mathrm{M}^{+}, 7 \%\right), 228$ (1), 158 (12), 143 (1), 131 (100). Anal. Calc. for $\mathrm{C}_{15} \mathrm{H}_{18} \mathrm{O}_{3}: \mathrm{C}, 73.15 ; \mathrm{H}, 7.37$; Found: $\mathrm{C}$, 73.03; H, 7.17.

3-Hydroxy-3-(5-methoxy-indan-1-ylidene)-2-methylpropionic acid ethyl ester (11)

Following the general procedure, a solution of $\mathbf{6 g}$ $(0.111 \mathrm{~g}, 0.426 \mathrm{mmol})$ in HOAc $(2.4 \mathrm{~mL})$ was reacted with TTN. $3 \mathrm{H}_{2} \mathrm{O}(0.379 \mathrm{~g}, 0.853 \mathrm{mmol})$ for $2 \mathrm{~h}$. Purification of the crude product by flash chromatography (hexanes/ EtOAc, 10:1) gave 11 (0.0853 g, $0.307 \mathrm{mmol}, 72 \%)$, as a yellow oil. IR (film) $v_{\max } / \mathrm{cm}^{-1}: 1734 ;{ }^{1} \mathrm{H}$ NMR $(300 \mathrm{MHz}$, $\left.\mathrm{CDCl}_{3}\right) \delta 1.11(\mathrm{t}, J 7.2 \mathrm{~Hz}, 3 \mathrm{H}), 1.59(\mathrm{~d}, J 7.2 \mathrm{~Hz}, 3 \mathrm{H})$, 2.85-3.00 (m, $4 \mathrm{H}), 3.84(\mathrm{~s}, 3 \mathrm{H}), 4.04-4.15(\mathrm{~m}, 2 \mathrm{H})$, 4.38 (q, J 7.2 Hz, $1 \mathrm{H}), 6.77-6.80$ (m, $2 \mathrm{H}), 7.34-7.40$ (m, $1 \mathrm{H}) ;{ }^{13} \mathrm{C}$ NMR $\left(75 \mathrm{MHz}, \mathrm{CDCl}_{3}\right) \delta 13.91,15.59,25.53$, $28.78,39.49,55.32,61.03,112.00,113.91,124.51$, 127.80, 139.04, 139.49, 144.95, 160.74, 172.36; LRMS $\mathrm{m} / z$ (rel. int.) 276 (M+ $7 \%$ ), 217 (53), 202 (69), 184 (10), 174 (21), 159 (24), 144 (14), 130 (19), 115 (25), 102 (10), 91 (9), 77 (13), 65 (11), 43 (100).

\section{Acknowledgments}

The authors wish to thank FAPESP, CNPq and CAPES for their continuous financial support.

\section{References}

1. For an account concerning the synthesis of indans, see: Ferraz, H.M.C.; Aguilar, A.M.; Silva, L.F., Jr.; Craveiro, M.V.; Quim. Nova 2005, 28, 703. Available free of charge at http://quimicanova.sbq.org.br/quimicanova.htm.

2. For a leading reference concerning Indinavir $^{\circledR}$ (Name: Derythro-Pentonamide, 2,3,5-trideoxy- $N$-[( $1 S, 2 R)$-2,3-dihydro2 - h y d r o x y - $1 H$ - ind e n - 1 - y 1$]$ - 5 - [ ( 2 S ) - 2 - [ [ ( 1,1 dimethylethyl)amino]carbonyl]-4-(3-pyridinylmethyl)-1piperazinyl]-2-(phenylmethyl)- (9CI); CAS number: 150378 17-9), see: Dorsey, B.D.; Levin, R.B.; McDaniel, S.L.; Vacca, J.P.; Guare, J.P.; Darke, P.L.; Zugay, J.A.; Emini, E.A.; Schleif, W.A.; Quintero, J.C.; Lin, J.H.; Chen, I.-W.; Holloway, M.K.;
Fitzgerald, P.M.D.; Axel, M.G.; Ostovic, D.; Anderson, P.S.; Huff, J.R.; J. Med. Chem. 1994, 37, 3443.

3. For a leading reference concerning Aricept ${ }^{\circledR}$ (Name: $1 H$-Inden1-one, 2,3-dihydro-5,6-dimethoxy-2-[[1-(phenylmethyl)-4piperidinyl]methyl]-, hydrochloride (9CI); CAS number: 120011-70-3), see: Sugimoto, H.; Iimura, Y.; Yamanishi, Y.; Yamatsu, K.; J. Med. Chem. 1995, 38, 4821.

4. Ferraz, H.M.C.; Silva, L.F., Jr.; Tetrahedron 2001, 57, 9939.

5. Ferraz, H.M.C.; Silva, L.F., Jr.; Vieira, T.O.; Tetrahedron 2001 , 57, 1709 .

6. Ferraz, H.M.C.; Silva, L.F., Jr.; Synthesis 2002, 1033.

7. Ferraz, H.M.C.; Aguilar, A.M.; Silva, L.F., Jr.; Synthesis 2003, 7, 1031.

8. Ferraz, H.M.C.; Aguilar, A.M.; Silva, L.F., Jr.; Tetrahedron 2003, 59, 5817.

9. Silva, L.F., Jr.; Sousa, R.M.F.; Ferraz, H.M.C.; Aguilar, A.M.; J. Braz. Chem. Soc. 2005, 16, 1160. Available free of charge at http://jbcs.sbq.org.br.

10. Ferraz, H.M.C.; Grazini, M.V.A.; Silva, L.F., Jr.; Longo, L.S., Jr.; Synth. Commun. 1999, 29, 1953.

11. Katritzky, A.R.; Wang, Z.Q.; Wang, M.Y.; Wilkerson, C.R.; Hall, C.D.; Akhmedov, N.G.; J. Org. Chem. 2004, 69, 6617; Majima, K.; Tosaki, S.Y.; Ohshima, T.; Shibasaki, M.; Tetrahedron Lett. 2005, 46, 5377; Zhang, J.; Blazecka, P.G.; Angell, P.; Lovdahl, M.; Curran, T.T.; Tetrahedron 2005, 61, 7807.

12. Taylor, E.C.; Robey, R.L.; Liu, K.-T.; Favre, B.; Bozimo, H.T.; Conley, R.A.; Chiang, C.-S.; McKillop, A.; Ford, M.E.; J. Am. Chem. Soc. 1976, 98, 3037.

13. For a similar strategy, see ref. 6 .

14. The relative configuration was established by comparison to the NMR data of similar indans. See, for example, ref. 4 and 8.

15. The effect of electron-donating and electron-withdrawing groups in the thallium(III)-promoted ring contraction reaction has been previously discussed in ref. 7 and 9 .

16. The coordination of thallium(III) with carboxylic acids and derivatives, including esters, has been previously proposed. See, for example: McKillop, A.; Hunt, J.D.; Zelesko, M.J.; Fowler, J.S.; Taylor, E.C.; McGillivray, G.; Kienzle, F.; J. Am. Chem. Soc. 1971, 93, 4841; Taylor, E.C.; Kienzle, F.; Robey, R.L.; McKillop, A.; Hunt, J.D.; J. Am. Chem. Soc. 1971, 93, 4845; Larock, R.C.; Fellows, C.A.; J. Am. Chem. Soc. 1982, 104, 1900; Larock, R.C.; Varaprath, S.; Lau, H.H.; Fellows, C.A.; J. Am. Chem. Soc. 1984, 106, 5274.

Received: July 14, 2005

Published on the web: December 15, 2005

FAPESP helped in meeting the publication costs of this article. 